Japanese Participants at the International Studies

Conference and the Institute

of Pacific Relations in the

Twenty Years' Crisis

by Tomoko Akami

The Australian National University

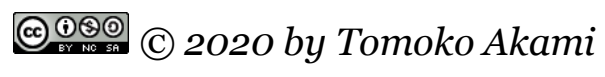

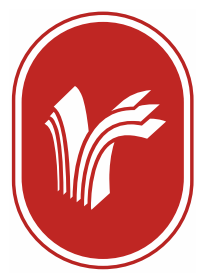




\section{Japanese Participants at the International Studies Conference and the Institute of Pacific Relations in the Twenty Years'}

\section{Crisis}

The proposed project for the research at the Rockefeller Archive Center (RAC) was "a re-assessment of the discourse of the International in the twentieth century." It was to examine how the idea of the "International" was formed. By the "International," I meant the counter-communist notion of the "International," which became the core of what we often term the "liberal international order" of the twentieth century. This research now forms a part of my broader book project. ${ }^{1}$ What follows here are my findings on one of the three focuses in this recent research at the RAC, which were also synthesized with documents from the League of Nations Archives and the Unesco Archives, and my thoughts on them.

This writing takes place in the unfolding of multiple crises. We are in the middle of the historic global pandemic crisis, which halted an ever-globalizing era of human history. Concurrently, we are experiencing an ongoing crisis of the globe, climate change, and that of parliamentary democracy. We are also in the middle of global BLM movements, while observing increasing power of non-democratic regimes. It is hard not to reflect on what the officers at the Rockefeller Foundation $(\mathrm{RF})^{2}$ were going through in the 1930s-1940s, when they watched their era's own crises unfolding, and were faced with "sinking international organizations," with which they "share[d] their objectives and admire[d] their work." 3 What did they think the RF should do? And what could we do? 


\section{The International Studies Conference, the Rockefeller Foundation, and the Notion of the International}

For my examination on the notion of the "International," I identified the International Studies Conference (ISC: 1928-1954) as a case study. The ISC4 was one of the programs of the International Committee of Intellectual Cooperation (ICIC) of the League of Nations, which aimed to establish "scientific study of international relations," with an ultimate goal to achieve peace of the world. ${ }^{5}$ It was, therefore, not an organization, but a series of conferences. The ISC was administered by the International Institute of Intellectual Cooperation (IIIC: 1926-46) in Paris, which was an executive office of the ICIC.

According to Rietzler, while the Rockefeller Foundation (or Laura Spelman Rockefeller Memorial) had been interested in projects in Europe in the field of international relations before the ISC began, it had a negative view of the IIIC before $1930 .{ }^{6}$ Only after the fifth ISC annual conference in May 1932 did the RF become aware of the IIIC's project, the ISC. Having recognized its value then, the RF gave the first of a series of grants to the IIIC for the ISC, starting with $\$ 1500$ in 1932. In 1935, the RF's Social Sciences division narrowed its scope to three areas, namely social security, public administration, and international relations, and identified the ISC as one of the most significant projects in Europe in the field of international relations. Accordingly, in 1935, the Rockefeller Foundation decided to give a substantial grant for the ISC $(\$ 30,000)$, followed by $\$ 40,000$ in 1936, and $\$ 100,000$ in 1937, making the ISC as the RF's "European flagship programme."7 Rietzler points out that this came at a critical time for the IIIC, when the League cut the budget line for the IIIC by $40 \%$, and the French government had taken similar steps. ${ }^{8}$

Accordingly, Rietzler maintains that the Rockefeller Foundation "moulded" the ISC into something that had little trace of its initial form. ${ }^{9}$ She nonetheless suggests the RF's influence in more normative terms, and points to its complex 
relationship with the US government, at least in the non-war period. As for the following years, Parmar argues more strongly that the RF was important in the rise of the discipline of international relations (IR) in the US in the 1950s, and that this contributed to an expansion of US hegemonic power in the Cold War era. ${ }^{10}$

Indeed, international relations (IR) scholars have now well-acknowledged the significance of the International Studies Conference and the Rockefeller Foundation in making the discipline of IR, especially in the US (and, therefore, in the world). ${ }^{11}$ Beyond this disciplinary history, the ISC also presents a crucial case study for the formation of the notion of the "International." Along with international law (IL), IR has been a most important field of knowledge which shaped this notion. Moreover, ISC conferences were a rare site in the inter-war period, where pioneering key figures in the field of international affairs, with diverse disciplinary backgrounds in various countries (largely in Europe and the US), gathered annually in 1928-1939 (and three times more in 1945-1954). As they discussed what should be this "scientific study of international relations," they were demarcating what was "legitimate" or "appropriate" as being "international." And this would define not only the academic discourse (disciplines) on the "International," but also how politicians and diplomats understood it in their public affairs, and how the people understood it in their everyday actions.

\section{Asia for the International Studies Conference, the Institute of Pacific Relations, and the Rockefeller Foundation}

I had three focuses for my research on the International Studies Conference, distinct from most existing works on the ISC, for my recent research at RAC. First, I wanted to look at the involvement of those from Asia, especially Japan, and if 
possible, China and India. Many relevant historical works on international organizations, including on the League of Nations, IR, IL, or the ISC so far had been largely focused on Euro-American contexts. A critical perspective on the formation of the notion of the "International" needs to encompass non-EuroAmerican sources and experiences, as well as their interactions with EuroAmerican counterparts.

Second, I wanted to examine whether, or how the International Studies Conference dealt with Asia as a subject of study. Third, this question has prompted me to examine the relationship between the ISC and the Institute of Pacific Relations (IPR, 1925-60), for which the RF was also the main funder until its end in 1960.12 Long and Riemens refer to the IPR's influence in the ISC, ${ }^{13}$ and Pemberton argues that the IPR, not the ISC, pioneered "the study of international relations on an international basis," and the ISC modelled after it. ${ }^{14}$ The ISC also adopted the IPR's conference format. Furthermore, Rietzler suggests that the Rockefeller Foundation pushed the politicization of the ISC, because it wanted to mould the ISC into an IPR model, which the RF regarded as a success case. ${ }^{15}$

Yet, the Institute of Pacific Relations pioneered not only international research programs on international relations, but also those on what were soon called "area studies" (Asian studies and Pacific studies). ${ }^{16}$ Distinct from the previous "Oriental studies" that focused on classics and literature, IPR research programs examined contemporary economic, social, political, and strategic issues in regional relations, utilizing social scientific methods and frameworks, Asian languages, and field work. Unlike the ISC, the IPR was an international non-governmental organization in Asia and the Pacific region, with a permanent secretariat (the International Secretariat of the IPR, ISIPR). Like the ISC, the IPR held international conferences (thirteen times between 1925 and 1958), but mainly in its region. And unlike the ISC, members from countries in Asia, such as Japan, China, and later India, played a significant part in its international conferences and research programs. ${ }^{17}$ How did the "fields of knowledge" of, and their experts at, the ISC and the IPR intersect? 


\section{Japanese Participants at the ISC Conferences in 1928-1939}

While both the International Studies Conference (1928-54) and the Institute of Pacific Relations (1925-60), therefore, were regarded as projects in the field of international relations and funded by the $\mathrm{RF}$, one significant difference was active involvements of the participants from Asia in the IPR. The Japanese Council of the IPR (JCIPR), formed in 1926, especially had been an enthusiastic partner of American experts who articulated a vision of the "Pacific community" of political equals in the IPR. Its members contributed substantially to IPR conferences and international research projects, except for the period between 1939 and $1945 .{ }^{18}$ Although Long suggests the ISC's global scope, ${ }^{19}$ the organization was largely Europe-centred with strong US involvement, not only in its memberships, ${ }^{20}$ but also in its scope of the selected topics and research projects. Did the Japanese participate in ISC conferences? If so, when? And who participated? How did they interact with their counterparts from Europe and the US?

Although information on Japanese participation in ISC conferences was scarce, after synthesizing the documents at the RAC with those at the other archives and other sources, a certain picture began to emerge.

\section{9-1933: Trying to Make the Japanese Council of the Institute of Pacific Relations as a "National" Member Institute for the ISC}

The International Studies Conference started essentially as a European project with involvement and support of US experts and philanthropic funds. No nonEuro-Americans were in a scope or involved in the first ISC conference in Berlin 
in 1928, and there was no reference to Japan or any Japanese institution in its conference planning documents, invitations, or proceedings. ${ }^{21}$ The ISC's pretention was, however, "global," as its founding figures believed Europe still remained the center of the world. ${ }^{22}$ At the same time, as the League's Council could claim a "global" status because it included Japan as its member, the ISC wanted to be a conference of a global reach, and intended to include countries in other regions, such as Japan, China, Australia, and New Zealand. ${ }^{23}$

The first Japanese participation at the ISC was recorded at the second ISC conference in London in 1929. Then, one Japanese individual, Hirai Sanji (surname first for Japanese names) of "Tokyo University," was listed as a "representative of Japanese institutions for the scientific study of IR." 24 There is little information on what led to this first "participation." Little is also known about Hirai, other than that he was an economist, and most likely from Tokyo Imperial University. Why he was "selected" is not clear, either. Judging from a pattern emerging in the following years, it may be because he "happened to be" in London for his own studies or for other conference obligations. Despite rapid development of the steamship liners, a trip to Europe was still a major financial and time commitment for any employer or employee in Japan.

Nevertheless, by the 1910s, prominent Japanese experts had been participating in international conferences, be it in the field of medicine, law, geography, geology, mathematics, chemistry, or biology, often with a subsidy of the Japanese Ministry of Foreign Affairs (MOFA) or other relevant ministries. Moreover, these experts were closely engaged with the development of their fields in Euro-America. The Japanese Society of International Law (JSIL, established in 1897), for example, started its own journal, Kokusaihō zasshi [Journal of International Law], in 1902, ${ }^{25}$ and it recorded close communications between the JSIL and the two leading "international" organizations, namely the Institut de Droit International (IDI, founded in Ghent in 1873) and the International Law Association (ILA, founded in Brussels in 1873), including the detailed agenda of their respective annual conferences. While JSIL members discussed these agendas in detail in the journal, the journal also recorded the participation of JSIL members at these conferences. In addition, the JSIL had good contacts with the Carnegie Endowment for International Peace (CEIP: 1910-) soon after the latter was 
established. The CEIP began to contribute funds to the journal after 1913, because it saw this journal as the only one in the field in the Orient, and it had an important mission to disseminate an idea of international law in this "rising Oriental power" and in the region. ${ }^{26}$

Unlike the JCIPR's participation in the Institute of Pacific Relations conference in the same period, Japanese participation in the International Studies Conference in 1929, however, was not regarded as proper "national" representation by the ISC. For this to occur, ISC executives had to evaluate the quality of key institutions in Japan to see whether they were competent to conduct credible research in the field of international relations and whether they could do so on a long-term basis. The International Institute of Intellectual Cooperation (IIIC), the administrative office for the ISC, was keen for those institutions to form a "national coordinating committee," which could coordinate research projects in that country for ISC conferences.

For a country where a representative institution or a national coordinating committee was yet to be formed, the IIIC needed to identify such an institution. In October 1930, Werner Picht, head of the university relations section of the IIIC, contacted "Aoki" at a hotel in Paris, and asked to meet him on the following day to discuss Japanese collaboration with the International Studies Conference, as well as the "handbook of non-partisan references centres." ${ }^{27}$ This was most likely Aoki Setsuichi, director of the Tokyo Office of the Information Section of the League of Nations in 1925-1933, ${ }^{28}$ who must have been visiting Paris for Leaguerelated business. In Paris, there was the Japanese Empire's Office for the League of Nations, which the Ministry of Foreign Affairs had set up in 1921. ${ }^{29}$ The Japanese ambassador to France was in charge of this office, and also represented Japan at League's Council and Assembly meetings.

What Aoki did in Japan for facilitating Japanese participation in the ISC is not clear, as no development was recorded in 1931 and 1932. Aoki was indeed in the milieu of those who were interested in international (including regional) affairs in Tokyo. They were a small group of the imperial/national male elite from the top universities and the high offices across the Japanese empire. By 1930, they 
were clustered mainly in three organizations, all headquartered in the imperial metropole, Tokyo. These organizations were: the JSIL (1897-), the Japanese Association of the League of Nations (JALN, 1920-), and the JCIPR (1926-), with respective memberships overlapping substantially. ${ }^{30}$ Aoki worked closely with the JALN for propaganda (public education) of the League, but knew key members of these organizations. It is most likely that he mentioned about the ISC to these members.

All these members, including Aoki, however, had a bigger issue to focus on in September 1931-March 1933: the diplomatic crisis created by the Japanese army garrison's aggression in Northeastern China (Manchuria) and the Japanese government's response to the League's assemblies, its inquiry mission, and its final resolutions. Their expertise in international law, international politics (a newly emerging academic field in Japan in the 1920s-1930s), international organizations, Euro-America, and Asia, was vital for the Japanese government in this crisis. Only a few of these experts voiced criticism of the Japanese government's position to justify the Japanese military actions and the subsequent military occupation of Manchuria and a part of Inner Mongolia, as a majority tried to defend the official stance. ${ }^{31}$

A significant new development in Japanese participation at the International Studies Conference nonetheless was recorded in late January 1933. Some contact must have, therefore, occurred in 1932 at the height of this Manchurian crisis, and here, it became clear that the IIIC's contact was the JCIPR. Shortly before the League's Assembly would vote for the resolution of the crisis against Japan's wishes, the fourth executive committee of the ISC noted that the National Coordination Committee for the ISC would probably be formed in Japan in the spring of 1933. The minutes stated: a special effort would be made [by a Japanese group] to submit a memo on "the State and Economic Life" [the theme of the sixth ISC conference, scheduled in London for 29 May-2 June 1933]; it was hoped that [the Japanese group] could participate the conference. It further noted: the ISC had wanted Japanese participation at the ISC for some time, which seemed to be now assured; when the coordinating committee was formed, it should be admitted as a member of the conference; and the executive committee [of the ISC] asked the IIIC to inform this to the JCIPR. ${ }^{32}$ Then, two months later (late March 1933), 
the Japanese government declared a withdrawal from the League (to become effective in March 1935).

No Japanese participant was recorded at the 1933 ISC conference, but its report noted that the conference decided that "the Japanese Council of the Institute of Pacific Relations [JCIPR] alone could be regarded as qualified for admission to the conference." 33 It appears, therefore, that the ISC decided that rather than waiting for the national coordinating committee to be formed in Japan, it would give the JCIPR a status of the "national" representative institution. This meant that the ISC understood that the JCIPR cleared the required conditions of scholarly standards and the capacity to sustain the necessary level of research. The JCIPR indeed consolidated prominent experts of the fields relevant for examining international and regional affairs with an extensive membership overlap with the JSIL and the JALN. ISC executive members must have been informed about the JCIPR by the representatives of the IPR at the ISC. They included John B. Condliffe (research secretary of the ISIPR, 1927-1931) who attended the ISC conference in 1930 and 1933 (and later, he would serve as general rapporteur in charge of the research programs for the ISC conferences of 1938 and 1939), and Edward Carter (director of the American Council of the IPR in New York, later appointed as secretary general of the International Secretariat of the Institute of Pacific relations at the coming IPR conference in Banff in August 1933). ${ }^{34}$ While Carter was involved in the ISC during this period, he was also based in New York, and had close contacts with the Rockefeller Foundation headquarters there. His skill at securing RF funding for the IPR gave him power at the ISIPR. Closely examining these funding applications by the IPR on a regular base, the RF also had a good understanding of IPR's international activities, including the JCIPR, while John D. Rockefeller 3rd participated in the Kyoto IPR conference in 1929.

This "almost done" stage of the Japanese Council of the Institute of Pacific Relations becoming the national unit for the International Studies Conference in mid-1933, however, seemed to be suspended for half a year, as the fifth executive meeting of the ISC in January 1934 recorded "renewed" negotiations with the JCIPR. It then noted almost a repeated decision that if there were no further 
organizations, the JCIPR "should be admitted to the conference in its individual capacity.”35

Although International Studies Conference documents did not reference it, which itself is remarkable, a particular question remains. Was this back step related to the Japanese government's notification of its withdrawal from the League in March 1933? If so, why did it not affect the ISC's decision in June 1933, but did so later in the year? Japan's withdrawal was to become effective only in two years' time in 1935, and this meant little change of Japan's presence at the League in 1933-35. Even after 1935, Japan also remained in "technical committees" of the League, especially its Permanent Mandate Commission, until it began war with China in 1937.

The years 1933-35 were a significant transitional period for Japan's foreign policy, and it will be wrong to see it as the beginning of "isolation" from the world. Rather, during this time, the Japanese government prepared for diplomacy without and outside of the League after 1935. This was why Hirota Kōki, who became foreign minister in September 1933 (and kept this post until spring 1936), strengthened the Ministry of Foreign Affairs' capacity for news and cultural propaganda, launched "cultural diplomacy," and shifted the center for Euro-American propaganda from Geneva to New York. ${ }^{36}$ It is nonetheless possible that this transition of Japan's status at the League and its foreign policy created some confusion for the executives of both the International Institute of Intellectual Cooperation and the ISC.

In 1933, however, foreign policy makers in Japan continued to regard JCIPR's participation in IPR conferences as important. To be sure, the circumstances surrounding the JCIPR were changing. Reflecting tension between the Japanese government and the League, as well as with the US administration, the Tokyo Metropolitan Police had described the JCIPR as "an enemy sympathizer" at the beginning of 1933. ${ }^{37}$ In May 1933, however, Matsuoka Yōsuke, who was the plenipotentiary chief of the Japanese diplomatic delegation at the League's Assembly earlier in February, wrote to Foreign Minister Uchida Yasuya. He noted, "Having discussed the matter with prominent people in London, New York, and Honolulu, I am convinced that Japan will need to take great interest in [the IPR], 
and I hope that you will understand this" and would "assist in sending powerful delegates to the coming IPR conference [in Banff in August 1933]." ${ }^{38}$ Although Matsuoka led the Japanese delegation's “exit” from the League's Assembly (as instructed by the Japanese government), he urged that Japan needed to be engaged with these non-governmental international conferences, and especially IPR's conferences. At the same time, for him, the objective of sending Japanese participants to these conferences was not to maintain "liberal," "scientific," and "impartial" exchanges of the views to solve the problems which challenged peace and security of the region, but to "make Japanese points of view understood" among leading experts of international affairs in the countries which mattered.

\section{4-39: The JCIPR and the ISC}

Possibly prompted by Matsuoka's suggestion in May 1933, and then Foreign Minister Hirota's "new engagement" with the world after September 1933, Japanese members attended ISC conferences every year between 1934 and 1939. Contrary to the "decisions" of the ISC in 1933 and 1934, however, the Japanese Council of the Institute of Pacific Relations did not seem to have gained a formal member institution status at the ISC in 1934-39.

Was it because of Japan's non-member status at the League? Up until early 1936, however, the International Studies Conference appears to have maintained negotiations on the JCIPR's admission. The JCIPR was referenced in the conference participant list for the seventh ISC conference (on collective security) in Paris in $1934 .{ }^{39}$ The seventh executive meeting of the ISC in December 1934 noted that the ISC was in contact with the JCIPR; its members attended the ISC conference in Paris in 1934, but JCIPR's affiliation was pending. The meeting asked the International Institute of Intellectual Cooperation to invite not the JCIPR, but "a competent Japanese scholar or group of scholars to submit a memo on Collective Security [the theme of the eighth ISC conference in London in 1935] and to take part" in the conference. $4^{40}$ The draft agenda of the eighth executive meeting of the ISC in mid-1936 noted that "the institute [the IIIC] was inviting 
the Japanese institutions and scholars to take part in the study on 'Peaceful Change" [the theme of the ninth ISC conference, scheduled in Madrid, for 27-30 May 1936].41 The French version of the resumé of deliberations of that meeting indicated that the ISC was still in contact with the JCIPR, discussing its admission as an ISC member institute. $4^{2}$ The fact that the IIIC was trying hard to get Japanese (and Chinese) involvements in the ISC in this period was also seen in the correspondence between the Rockefeller Foundation's Paris office and its New York office. A few days after the above-mentioned eighth executive meeting at the IIIC in Paris, Tracy Kittredge at the RF Paris office wrote to Sydnor Walker, associate director of the RF's Social Sciences division, that the IIIC appointed Fergus Chalmers-Wright as a "means of assuring cooperation from Far Eastern countries" on the ISC. 43 Walker's response suggested that the issue was a concern for the RF.44

The ninth ISC conference agenda of May 1936, however, noted that "invitations to attend the $9^{\text {th }}$ ISC have also been accepted by individual scholars and experts in Germany, Hungary, Japan, Norway, Portugal and Sweden," with no reference to the JCIPR. 45 For the following ISC conferences of 1937, 1938, and 1939, Japanese participants did not appear in the formal lists of the conference participants but, instead, recorded in other conference documents or in correspondences of the officers of the RF as participants attending in a "personal capacity." 46

What prevented the JCIPR from admission as an ISC member institute in 193536 may be partly due to the re-organization of the JCIPR in 1935. The change reflected the strong "public diplomacy" initiative of Foreign Minister Hirota in the post-League era. In May 1935, shortly after Japan's withdrawal from the League became effective, the government decided to "merge" the JCIPR into the Japanese International Association (JIA), and this took place at the end of the year. The JIA was formally the Japanese Association of the League of Nations (JALN). When Japan's withdrawal became effective, it was not dissolved, but reorganized with a new name and new objective. Its objective changed from "promoting the spirit of the League" to "promoting friendly relations and cooperation among nations and contributing to the establishment of international justice and the realization of international peace."47 
This merger was a step towards making the Japanese Council of the Institute for Pacific Relations a part of Japan's cultural diplomacy/propaganda and intelligence machinery, although government pressure became more blatant after the outbreak of Japan's war with China in mid-1937. To be sure, some government officials thought the JCIPR (now a section within the Japanese International Association) should withdraw from the Institute of Pacific Relations' international conferences and research programs. Shortly after the sixth IPR conference at Yosemite in 15-29 August 1936, Amō Eiji, then director of the Department of Information of the Ministry of Foreign Affairs, told the director of the JIA that the JCIPR should withdraw from the IPR, which he saw an organization of "white supremacists." 48

JCIPR members, however, continued engagement and communication with the International Secretariat of the Institute for Pacific Relations, even after having learned about its new international research project on the Sino-Japanese War in early 1938. They attended a study conference at Edward Carter's farmhouse in Lee, Massachusetts, trying to modify the key points of the project in August 1938, and then at Princeton from December 1938 to January 1939. Having failed that, the JCIPR finally notified the Pacific Council, the IPR's executive body, in July 1939 that it would withdraw from the ISIPR's Inquiry project. ${ }^{49}$ The JCIPR instead conducted its own "inquiry" on the war. The IPR's Yosemite Conference in August 1936, therefore, became the last IPR conference the JCIPR attended before the war. The next IPR conference the JCIPR would attend was the eleventh conference held in Lucknow, India, in 1950, when Japan was still under the Allied occupation.

Japanese regular participation at ISC conferences, therefore, began after 1934, and largely in the period when the JCIPR was merged with the JIA, or coopted into the state machinery, and when it stopped participating IPR conferences. To be sure, the JCIPR was never independent from the government from its beginning in 1926. Although it was not revealed publicly, the Ministry of Foreign Affairs gave subsidies to the JCIPR for its overseas conference participation. The JCIPR's holding of the third conference in Kyoto in 1929 would not have been 
possible without the support from MOFA as well as from major conglomerates..$^{\circ}$ Its overseas participants were given smooth custom services and free railway tickets across the Japanese empire, including Korea and Manchuria. Although many stressed the significance of "non-governmentality" of the IPR then, anyone, who thought these massive logistic arrangements were possible without extensive official involvements, would have been deluded. Furthermore, JCIPR members were imperial/national male elite, who felt a mission and duty for the nation and empire, and except for a few, many were to defend official policies. Their expertise, language skill, and knowledge of and familiarity with foreign countries, all made them ideal publicists for Japan's foreign policy to Euro-American powers.

\section{Who were the Japanese Participants at the ISC, 1934-39?}

If the Japanese Council of the Institute of Pacific Relations did not become an ISC's national institution, who attended ISC conferences from 1934 to 1939? Through what channel was this arranged? What impact did their experience at ISC conference have in their understanding of the "International"? And were ISC conferences a site for "public diplomacy" for them?

In the 1930s, a new generation of members was emerging at the JCIPR and in the field of international politics, and although they were not regarded as one coherent group, I have used the term, "statist reformism" (kakushin-shugi), to capture a certain intellectual and ideological trend among them. ${ }^{51}$ It was a statist version of welfare "liberalism," which argued for state-led reforms for the whole of society. Recognizing the problem of parliamentary democracy, some were influenced by the Fabians and/or other social democratic thought, and argued for guild socialism. Although they were largely anti-fascist, many identified Japan as a "have-not country," similar to Germany and Italy, and argued for the need to reform the current international order, which they saw was dominated by the Anglo-American powers. This was why German "renovationist" scholars of 
international law and geopolitics, such as Carl Schmitt, became influential among them. In the mid- to late 1930s, this trend was strongly evident among a younger generation of JCIPR members, some of whom were to be involved in policy formations of the New Order (domestic) and the East Asia New Order as members of the brain trust of Prime Minister Konoe Fumimaro in 1937-39, and 1940-41.52 These JCIPR members included Rōyama Masamichi (1895-1980), Matsumoto Shigeharu (1899-1989), and Matsukata Saburō (1899-1973).

Uramatsu Samitarō (1901-1981), whose name was listed in a note of the participants of the eighth ISC conference in London in 1935, but not in the formal list, 53 was one of these young JCIPR members. After graduating from Tokyo Commerce University (now Hitotsubashi University), he became a journalist, and joined the JCIPR as one of the secretaries for the Kyoto IPR Conference in 1929 with Matsumoto and Matsukata. After the conference, Uramatsu joined the Political and Economic Research Institute with Rōyama and Matsumoto, ${ }^{54}$ and later was involved in Konoe's brain trust. In 1935, he was most likely studying at a university in London.

Names of the other participants who attended ISC conferences in 1934-39, however, suggest different groups, although connected to the JCIPR, from these younger JCIPR members. One was a group of established international law professors, based more at the Japanese Society of International Law, and more familiar with Europe than the US, and another was that of company executives who were posted in Europe.

For the ISC conference (on collective security) in Paris in May 1934, three Japanese were listed: Tachi Sakutarō, Asano Ryōzō, and Komatsu Takashi. 55 Asano Ryōzō (1889-1965) was a Harvard graduate (1912), and the second son of the founder of the Asano Conglomerate. After his father passed away in 1930, he became virtually in charge of the conglomerate. These conglomerates, such as Asano, Yasuda, Sumitomo, Mitsui, Furukawa, as well as Yokohama Specie Bank, had been major donors to the JCIPR and the JALN. ${ }^{56}$ Asano first worked at the San Francisco branch of the Oriental Steamship Company (in the Asano group). Back in Japan, he entered into the management of various companies in the 
group. In 1934, he was vice president of the Asano Cement Company and president of the Tsurumi Shipbuilding Company (also in the group). Asano was to attend an annual conference of the International Labor Organization at Geneva, 4-23 June, as a representative of the employers in Japan. ${ }^{77}$ Most likely, the JCIPR and/or MOFA asked him to attend the ISC conference in Paris on 2426 May. Although Asano was no scholar on the theme of the ISC conference, collective security, he was fluent in English, had extensive knowledge of global and regional trading relations, which were contentious issues for peace and security then, and was close to policy makers in Japan. He probably fitted well as a type of "men of public affairs" whom the Rockefeller Foundation was keen to involve more at the ISC.

Komatsu Takashi was director of the Tsurumi Shipbuilding Company, and was accompanying Asano to the ILO conference. $5^{8}$ Komatsu was, however, more than a minder of Asano, and probably he had more relevant expertise (naval disarmament) to the ISC conference theme. Graduated Harvard one year before Asano in 1911, he became the secretary to the president of the Oriental Steamship Company, before he was posted as the head of the New York branch of the company. He then joined the shipbuilding company. In the 1920s, he attended as a member of the Japanese diplomatic mission at the Washington Conference (1921-2) and the Geneva Disarmament Conference (1927).59

Tachi Sakutarō (1874-1943) represented another group of Japanese participants at the International Studies Conference; he was an international law expert and member of the Japanese Society of International Law. Tachi also attended the ISC conferences in 1936, as well. He was professor of international law at Tokyo Imperial University until he retired in March 1934. Tachi was a founding member of the JSIL in 1897, when he just graduated from the Faculty of Law (Political Science) of the university and started graduate studies in international public law. He remained a central figure at the JSIL throughout his life. After studying in Europe in 1900-4, Tachi was appointed as professor at the university in 1904, and taught diplomatic history, and then international law after 1905. He was a prolific, influential writer. Tachi's works could be summarized as contributing to the new study field of international politics from a perspective of international law. 
Although Tachi was formally appointed as an advisor to the Ministry of Foreign Affairs in December 1934 after his retirement from the university, like many international law experts at the JSIL, he had played this advisory role throughout his academic career. Tachi did so in a number of ways. First, as an expert member of the diplomatic delegations, he advised the government at major intergovernmental conferences, such as the Conference on International Law on Armed Conflicts at Sea in London in 1909, the Paris Peace Conference in 1919, the Washington Conference in 1921-1922, and the Hague Conference for the Codification of International Law in 1930. Second, he regularly advised MOFA on foreign policies. Third, he tried to insert "Japanese interests" into the codification process of international law. ${ }^{60}$ Fourth, he often "legally" defended governmental policies to experts and the public in Japan and overseas, such as at the time of the Manchurian Crisis. ${ }^{61}$

A full analysis of the significance of Tachi's interactions at the ISC conferences in 1934 and 1936 is yet to be conducted.62 It is, however, important to note that in 1934-43, he worked within MOFA, and his advice was well sought after by high officials. ${ }^{63}$ In 1934 and 1936, the ISC was a useful place for him to know how experts were understanding current international affairs, especially European politics and the League. This information was probably more useful for MOFA than Tachi conducting Japanese propaganda at the ISC.

As it was the case for Asano, the International Studies Conference attendance was an "extra" to Tachi's "main" objective. The Japanese Society of International Law's journal recorded that Tachi had left Japan at the end of March 1934 "in order to attend the [Institut de Droit International's] conference" at Brussels in that year, and reported about this conference to JSIL members in November 1934, upon his return. ${ }^{64}$ In 1936, the only record in the journal was his talk at the JSIL meeting in October about "an international conference" he had attended in Europe earlier in the year. At that same meeting, another central figure of the JSIL (and the Japanese International Association), Yamakawa Tadao, former diplomat, high official, and member of the House of Peers, who was instrumental in the JCIPR's merge to the JIA, also gave a talk on the Institute of Pacific Relations' Yosemite Conference of 1936 which he had attended. He reported that 
he was successful in "correcting misunderstandings of Japan" among IPR conference participants there. 65

In addition to Tachi, two other names, Tanaka Kōtarō (1890-1974) and Satō Junzō, appeared in a provisional list of participants for the ninth ISC conference on "peaceful change" in Madrid in 27-30 May 1936. ${ }^{66}$ Tanaka was a prominent professor of law at Tokyo Imperial University. Studied in Europe and the US, he became professor of commercial law at the university in 1923, became a Catholic in 1926, and wrote Theory of World Law [Sekai hō no ronri]. ${ }^{67}$ Little information is available about Satō, other than that he was director of la Maison du Japan de la Cité internationale universitaire de Paris, which was established in 1929 by a Japanese business man initially for lodging Japanese students. ${ }^{68}$ He most likely had close contacts with academics at the University of Paris, the International Institute of Intellectual Cooperation, Japanese diplomats, and the Japanese business community in Paris.

The tenth ISC conference on "peaceful change" was held in Paris on 28 June-3 July 1937, ending only a few days before the first clash between Japan and China, which was to lead to the second Sino-Japanese War. Although the conference list only mentioned that Japanese observers attended the conference, ${ }^{6}$ the JSIL journal recorded on these participants in its newsletter. Here, one can see a similar pattern of the Japanese group as in 1934 and 1936: a senior and close-togovernment JSIL member who was also attending an international law conference. Yamada Saburō (1869-1965), professor of international private law at Tokyo Imperial University, and a founding member of the JSIL, reported to the JSIL meeting on 27 October 1937 (Japan was already at war with China) on the ISC conference. Yamada noted that he attended an annual meeting of the International Law Association in Luxembourg on 30 August-4 September, as well as the ISC conference on peaceful change at the University of Paris and the second anti-nuclear law conference at The Hague. At the ISC conference, he was in the group on "resource problems," and argued for the abolishment of discriminatory tariffs. Yoshisaka Shunzō (1889-1958, former Japanese representative at the ILO, Geneva, and consultant for social affairs to the Home Ministry), also attended the roundtable on "population problems."7o 
Yamada was an active contributor to the JSIL journal. He was known for his works on colonial law and the legal status of foreigners, including rights of Japanese migrants in California, and promoted Japan-French relations. He was the head of the law faculty at Tokyo Imperial University in 1921-24, and chancellor of Keijō Imperial University (Seoul) in 1931-36 in colonial Korea. In addition to his fluency in French, his works were relevant to the theme of the ISC in $1937.7^{11}$

The war with China was no obstruction to Japan's wartime public diplomacy (propaganda) to Europe and North America, or in fact, it enhanced, consolidated, and strengthened these activities. In May 1938, the Ministry of Foreign Affairs established the Japan Institute at Rockefeller Center in Manhattan, which was modeled after the British Library of Information, also located in the same building. The Japanese government wanted to tell the "right" story of Japan's policy towards China to the powers in Europe and the US, and regarded members of the JSIL or JCIPR as ideal publicists. ${ }^{22}$ There were only a few avenues left in Europe, and the ISC was one of them.

In this exact timing, the eleventh ISC conference on economic policies was held in Prague on 23-27 May 1938, which was to prompt the most significant initiative for an International Studies Conference study project by a Japanese group. Here, it is important to note that Japan's war with China, despite the news of its atrocities in Nanjing, did not seem to trouble the IIIC, ISC executives, or the Rockefeller Foundation. Neither was it a source for them to argue against Japanese participation at the ISC. In fact, they responded to this Japanese research initiative positively, and the $\mathrm{RF}$ was to provide a grant $(\$ 1000)$ for a Japanese project for 1938 through the IIIC for the first time.

The person, who took this initiative, and who was in charge of communications with the International Institute of Intellectual Cooperation in 1938-39, was Mitsui Takasumi (1901-1979. He was the second son of Mitsui Takamine, the tenth head of Mitsui Kitake that was one of the two most direct male lines of the Mitsui families and the most powerful in the Mitsui Conglomerate. His brother was Mitsui Takakimi, the eleventh head of the family and president of the Mitsui Conglomerate after 1933. Mitsui Takasumi was, however, more an academic and 
educator. He studied economics at Tokyo Imperial University and went to Oxford in the 1930s. There, he was involved in the Oxford Movement (1921-), which became the Moral Re-Armament Movement (MRA) in May 1938. It was the movement against fascism and communism, to achieve happiness and peace by reviving oneself, family, factory, company, nation, and the world by honestly following Christ's teachings. Back in Tokyo, he started a small school in 1940 for children of the families who returned from overseas postings, which became the boarding school, Keimei gakuen, in 1943 with a building and a large property given by his brother. The school motto was "to nurture a person with a broad view, rich personality, original perspective, and world perspective."73 MRA, therefore, had a profound impact on him. The school became his life work, and he maintained his commitment to MRA until the postwar period.74

Mitsui attended the ISC conference in 1938.75 He was most likely still at Oxford, and travelled to Prague for the conference. RF officer Tracy Kittredge reported to Sydnor Walker, then acting director of RF's Division of the Social Sciences, on "the active participation of four Japanese personalities" at the conference, although not naming their names. ${ }^{76}$ Kittredge noted that "after the meeting in Prague, the Japanese delegates draw up a complete program of preparatory studies on the subject of the next conference." Condliffe, who was general rapporteur of the ISC conferences of 1938 and 1939, was "particularly interested in obtaining these Japanese studies," and Mitsui worked out the details "after extensive discussion with Condliffe."77

Almost straight after the conference, Mitsui wrote to Henri Bonnet, director of the IIIC, on 22 June 1938, and explained the proposed preparatory studies by the Japanese group on the subject (economic policy) of the twelfth conference. The Japanese group's plan was, first, to prepare the minimum program requested by Condliffe and, second, to conduct a supplementary study on the development of Japan's foreign economic policy in 1870-1938. Its plan was to fund half the cost from local sources, and asked for the IIIC's assistance for the other half of the cost, $\$ 2000.78$

In this proposal, former members of the Japanese Council of the Institute of Pacific Relations (now at the Japanese International Association) were included 
as the collaborators for the minimum program research. They were: Royama Masamichi (Tokyo University) on "legal and administrative mechanisms which decide and administer foreign economic policy," and Yanaihara Tadao (18931961) on "international aspects of the recent economic policy." Mitsui added Mitsubishi Economic Studies Institute and Mitsui's Economic Research Section as other collaborating institutions. 79 These big conglomerates would be, therefore, supporting the research which was relevant to their company interests.

The inclusion of Yanaihara, described as a "former professor at Tokyo University," is noteworthy. Yanaihara had been a professor at Tokyo Imperial University, and taught colonial policies, which he took over from Nitobe Inazō when he was posted to the League's under secretary in 1920. Soon after the outbreak of the Sino-Japanese War in July 1937, however, Yanaihara published criticism of Japanese policy to China, as well as popular responses to the war, and in that December, he was forced to resign from the university. In June 1938, therefore, he was out of the university, but Mitsui included him as a collaborator. It indicates that Yanaihara continued his political economy work in this period. His research was indeed well regarded at the Institute of Pacific Relations; his study on the Japanese mandates in the Pacific, first published in Japanese in 1935, was to be published in English by the IPR as a part of its international research series in $1940 .{ }^{80}$

Kittredge asked Walker's opinion on his judgment on Mitsui's request on 30 June 1938. ${ }^{81}$ First, although Condliffe and Bonnet were in favour of funding a maximum of $\$ 1000$ per year for 1938 and 1939, he felt the supplementary study was not essential, and thought $\$ 600$ per year for two years was appropriate. Second, he also noted that: "[i]n the original budget of the Studies Conference, no allocation was envisaged for preparatory studies in Japan." ${ }^{2}$ Kittredge made this point to ask Walker whether the RF should give a grant to the Japanese directly, because this had not been in the IIIC's ISC budget. The point, nonetheless, revealed that there had been little active involvement of Japan, until Mitsui and his colleagues participated the conference in 1938. Maybe the topic, "economic policy," might have prompted this new enthusiasm, combined with Condliffe's push. 
On the second point, Walker preferred payment through the International Institute of Intellectual Cooperation ${ }^{83}$ Raymond Fosdick, president of the RF, agreed. There was, however, little indication that they preferred this method in order to avoid the RF's connection with Japan. ${ }^{84}$ On the first point, Walker did not comment. Leo Gross, Secretary of the IIIC, took Kittredge's point of dropping the supplementary study, but he argued that $\$ 600$ was "far below the Japanese estimate." Instead, Gross called for $\$ 1000$ per year for two years, and added the support for this amount by Bonnet, Condliffe, and Malcolm Davis (director of the Paris office of the Carnegie Endowment for International Peace (CEIP) since 1935. ${ }^{85}$ In early August, Kittredge came back to Gross with the approval, and new grants were given to the Japanese Committee (\$1000), along with those to the Roumanian Centre (\$500), and the Swiss Committee (\$1000). ${ }^{86}$

No opposition about Japan's war with China was made at the IIIC, by the ISC executives, the CEIP in Paris, or by the RF regarding Japanese participation at the ISC. Rather, they were keen to get the Japanese group involved at the twelfth ISC conference in 1939, now scheduled for Bergen, 27 August to 2 September 1939. (Nazi Germany invaded Poland one day before the ending of the conference.)

This Japanese participation in 1939, however, proved difficult because of Japan's strict financial restrictions. Mitsui here again worked hard, using his contacts to secure Japanese participation. On 12 May 1939, Mitsui, back in Tokyo, wrote a letter to Satō Junzō in Paris, and asked him to represent their ISC group. He explained that although they were "very anxious" to participate, it was impossible to travel abroad because of foreign exchange restrictions and little prospect of obtaining a required permission from the finance ministry. Mitsui stressed Satō's geographical closeness to Norway and his familiarity with the ISC, rather than his expertise on the conference theme. His group was asking the IIIC to assist with his expense as they could not transfer money to him. He also told Sato that they were asking Viscount Kanō in London to be a possible delegate, and thus asked him to send the information on the ISC and the IIIC to Kanō. ${ }^{87}$

Accordingly, the 1939 conference list file included Viscount Kanō Hisaakira (1886-1963), director of Yokohama Specie Bank (London); Satō Junzō, director of la Maison du Japan de la Cité internationale universitaire de Paris; and Iijima 
Sōjirō, director of the Yokohama Specie Bank, Paris. ${ }^{88}$ Kanō was an expert of international finance. After graduating from the faculty of law (political science) at Tokyo Imperial University, he joined Yokohama Specie Bank in 1912, and spent most of his time at overseas postings, starting from Dairen, then to New York, London, Calcutta, and back to London (in 1934). In 1939, he became a Japanese representative director at the Bank for International Settlements (BIS). ${ }^{89}$ On Iijima, a company record notes that he was still in France in June 1940, evacuating to Bordeaux with one secretary and one foreign employee. ${ }^{\circ 0}$ A full history of Japanese participants at the ISC, therefore, needs to be located in the context of networks of Japanese companies and their employees in Europe, on which little has been done so far. ${ }^{91}$

\section{As a Tentative Conclusion: Dictator Regimes and Public Opinion in the Crisis in the 1930 s and in 2020}

My initial aim to examine the nature of Japanese participation at the International Studies Conference was to see the ISC's engagement (or nonengagement) with Asia, and how this impacted ISC's shaping of the notion of the "International." What I have pieced together here is a skeleton, and further information and analysis is needed to understand the nature of their participation and their intellectual and personal engagements and interactions. Yet, a discovery of their regular participation between 1934 and 1939 may make their case more comparable to that of German participation at the ISC after 1933. One of the factors for which Rietzler regards the ISC as a missed opportunity and failure was its accommodation of dictator propaganda, especially by the German group under the Nazis after 1933, and, in particular, by a German jurist, Friedrich Berber. Although Germany was one of the main national units in the beginning of the ISC (the first conference was hosted in Berlin, 1928), it withdrew from the ISC after the Nazi Germany's withdrawal from the League. Berber, however, attended the ISC conference in 1935 as an observer, and his institute in Germany became an 
ISC member in $1936.9^{2}$

According to Rietzler, Berber conducted Nazi propaganda through the ISC networks, with substantial success in influencing thoughts of prominent ISC participants. In the 1935 conference, he lobbied for German access to colonies, which matched Ribbentrop's policy of German colonial expansion in Africa. Berber's "revisionist" views on international law and international politics were picked up by E.H. Carr, who attended the ISC conference in 1937, and who cited Berber's Security and Justice (1934) in his Twenty Years' Crisis. Arnold Wolfers, a well-respected Swiss-American political scientist at the ISC, also regarded Berber as a "moderate," respected his works, and "encouraged the Rockefeller Foundation to work with him at the ISC." 93 Berber also became even a member of the new board of the re-organized Geneva Research Centre (GRC) in 1936, which the RF wanted to be an alternative secretariat to the IIIC for the ISC. 94

If the ISC and the RF were too compromised by accommodating Nazi propaganda at the ISC and the GRC, could the same be said for Japanese participation? We have seen here little opposition by the IIIC, ISC executives, the CEIP in Paris, or the RF to Japanese participation. Rather, they were more eager to get them involved. It was a dilemma for the RF (and the IPR), which stressed the significance of 'impartial' and 'scientific' non-official exchanges of views, but which also wanted "impacts" in real politics.

In June 1936, shortly after the ISC conference in Madrid, the RF's main concern was with prevailing anxiety about the "present state of international relationships" in Europe. Thinking about the next conference in 1937, and gathering thoughts of "searching discussion" on the influence of the ISC at a dinner with the key ISC figures, 95 Kittredge sent a long note to Walker. Here, he argued why the ISC need to be engaged with experts of the "dictatorial great powers." Although he and the ISC key figures were thinking of Europe, and experts from Germany and Italy, Kittredge also included Russia and Japan as four “dictatorial great powers.” ${ }^{96} \mathrm{He}$ observed:

It was ... the general feeling [at the Madrid Conference] that it was not sufficient for this examination [by experts] to proceed in those 
countries still possessing democratic and liberal regimes ... [E]xperts in Germany, Italy, and Russia have even greater influence in the councils of government than scholars in the liberal countries.... It was for this reason that representatives of the German and Italian groups were welcomed at Madrid and every effort made to make them feel that their full participation and cooperation in the international discussions of the problems of the Conference were vitally important to the success of these discussions.

He then further argued:

In the world as it is today organized, it is perfectly apparent that the governments of Japan, Russia, Germany and Italy have their hands the final decision as to Peace or War. They need [sic] pay very little attention to any opinion except those of a small group immediately surrounding the effective head of the respective governments of these countries. The group in Madrid therefore felt very strongly that programs designed at the education and direction of public opinion in the liberal countries were not in themselves sufficient to assure a reasonable prospect of the intelligent and peaceful solution of international conflicts. ${ }^{97}$

Their "realistic" understanding of international affairs led them to argue for including experts from and research on these "dictator countries."

E.H. Carr was a strong critic of League supporters, calling them "utopians and idealists." His main criticism was their almost blind reliance on "public opinion" as a moral power which could sanction wrong state actions. By the mid-1930s, he had plenty of counter-evidence for their point. He, like Berber and Carl Schmitt, argued that idealists had to realize that the existing international laws and institutions were the results of power politics in which the dominant powers tried to maintain their order.

Yet, what is often neglected is that Carr also argued that realist positions were not enough either for academics and practitioners because they did not give a rationale or mechanism for change. The current order needed, as he continued, to have this venue for change in order to address injustice in it, and for this to happen, one needed to have a goal, an ideal. ${ }^{98}$ 
What was their goal for the ISC and the RF in the late 1930s? And, are we experiencing a similar crisis? What Kittredge grappled in 1936 has much relevance to what we face now:

In discussions on university teaching of international relations, it became perfectly clear that the proportion of the population that could be expected to have any intelligent and impartial understanding of foreign affairs was so small in every country as to be almost negligible... ${ }^{99}$

And educating public opinion may have an influence, but the process would be "slow and painful," and meanwhile public opinion would be influenced "by pressure groups of various kinds, representing definite special interests."100

Standing in June 2020, there is one significant change from the 1930s: a demagogue is in power of a leading liberal democratic regime. How did we get here? What would be our goal?

1 "Towards a Globalized History of Modern International Relations," funded by the Australian Research Council for 2020-2023. I thank Lee R. Hiltzik at the Rockefeller Archive Center (RAC) and the archivists at the League of Nations Archives and Unesco Archives for their great help for this research, and the grants from the RAC and the APIP, the ANU.

${ }^{2}$ Laura Spelman Rockefeller Memorial merged into the Rockefeller Foundation (RF) in 1929.

3 Willits to Fosdick, 13 Feb 1941, RG 3/Ser 910/Box 7/F 60, RF, RAC.

4 I refer to the ISC as a project/program name, and for its conferences, I used "ISC conference" for its conference(s).

5 On its origin in 1926, see Katharina Rietzler, "American Foundations and the "Scientific Study' of International Relations in Europe, 1910-1940," PhD thesis, University College London, 2009, 202-203.

6 The IIIC was initially established by the French Foreign Ministry, and had an autonomous status from the ICIC, which the ICIC found problematic. The IIIC was reorganized in 1930, after which the RF saw some improvement of its quality. Rietzler, "American," 192, 194.

7 Ibid., 213-214.

8 Ibid., 215

9 Ibid., 215.

10 Inderjeet Parmar, "Knowledge for Empire: American Hegemony, the Rockefeller Foundation and the Rise of Academic International Relations in the United States," in Jeremy Adelman ed., Empire and the Social Sciences: Global Histories of Knowledge (London: Bloomsbury Academic, 2019), 153-176. 
${ }_{11}$ David Long, "Who Killed the International Studies Conference?," Review of International Studies, 32 (4) (2006): 603-622; Michael Riemens, "International Academic Cooperation on International Relations in the Interwar Period: The International Studies Conference," Review of International Studies, 37 (2) (2011): 911-928; Jo-Anne Pemberton, The Story of International Relations, Part One, Part Two, Part Three: Cold-Blooded Idealists (Cham: Palgrave Macmillan, 2019, 2019, 2020); Jan Stöckmann, "Studying the International, Serving the Nation: The Origins of International Relations (IR) Scholarship in Germany, 1912-33," The International History Review, 38 (5) (2016): 1055-1088; Nicholas Guilhot ed., The Invention of International Relations Theory: Realism, the Rockefeller Foundation, and the 1954 Conference on Theory (New York: Columbia University Press, 2011).

12 Tomoko Akami, Internationalizing the Pacific: The United States, Japan and the Institute of Pacific Relations in War and Peace, 1919-45 (New York: Routledge, 2002); John Thomas, The Institute of Pacific Relations: Asian Scholars and American Politics (Seattle: University of Washington Press, 1974).

13 Long, "Who," 606; Riemens, "International," 917-918.

${ }_{14}$ Pemberton, The Story, Part One (The Story hereafter), 3.

15 Rietzler, "American," 220, 221.

${ }^{16}$ Thomas, The Institute; Hara Kakuten, Gendai Ajia kenkyū seiritsushiron (Tokyo: Keisō shobō, 1984); Warren Osmond, Frederic Eggleston: An Intellectual in Australian Politics (Sydney: Allen and Unwin, 1985).

17 Akami, Internationalizing.

18 Ibid.

19 Long, "Who," 619. Its reach to Latin American countries in the later period was, however, noteworthy.

${ }^{20}$ The IIIC, "Members of the ISC" [1937], included in Scroggs (American Coordinating Committee for International studies) to Walker, 9 Dec 1937, RG 1.1/Ser 100S/Box 105/F 956, RF, RAC.

${ }_{21}$ [A. Zimmern], "Report of the meeting of experts, Berlin, 22-24 March 1928," R2222/5B/5354/2072, League of Nations Archives (LNA).

22 Rietzler, “American," 221.

23 Pemberton, The Story, 391.

24 A. Zimmern, "Report of the Institute to the sub-committee of institutions for the scientific study of international relations, London, 7 June 1929," R2222/5B/12849/2072, LNA.

25 The title of the journal was changed to Kokusaihō gaikō zasshi [Journal of International Law and Diplomacy] in 1912.

26 "Kaihō," Kokusaihō gaikō zasshi [KHGZ], 11 (10) (1913), n.p.

27 Picht to Aoki, 8 Oct 1930, NOOCR-351/K.I. 1-a, Unesco Archives (UNESCOA).

${ }^{28}$ Tomoko Akami, "The Limits of Peace Propaganda: The Information Section of the League of Nations and its Tokyo Office," in J. Brendebach, M. Herzer, and H. Tworek eds., Exorbitant Expectations: Communicating International Organizations in the $19^{\text {th }}$ and $2 O^{\text {th }}$ Centuries (London: Routledge, 2018), 78-84.

29 Tomoko Akami, Japan's News Propaganda and Reuters' News Empire in Northeast Asia, 1870-1934 (Dordrecht: Republic of Letters, 2012), 132.

$3^{30}$ Tomoko Akami, "Experts and the Japanese Association of the League of Nations in the International Context, 1919-1925," in P. O'Brien and J. Damousi eds., League of Nations: Histories, Legacies and Impact (Melbourne: Melbourne University Press, 2018), 159-178. ${ }^{31}$ Mitani Taichirō, Taishō demokurashiron (Tokyo: Chūō kōronsha, 1974).

32 "Summary of the proceedings of the $4^{\text {th }}$ meeting of the executive committee of the ISC," Paris, 28-29 Jan 1933, R4006/5B/2381/2381/Jacket 1, LNA.

33 A. Zimmern, "Report on the administrative meeting [on the $6^{\text {th }}$ ISC], London, 29 May-2 June 1933," R4008/5B/5906/2381/Jacket2, LNA.

34 Akami, Internationalizing, 171-172. 
35 "Summary of the proceedings of the fifth meeting of the executive committee of ISC," 26 Jan 1934, R4006/5B/2381/2381/Jacket1, LNA.

${ }^{36}$ Tomoko Akami, Soft Power of Japan's Total War State: The Board of Information and Dōmei News Agency in Foreign Policy, 1934-45 (Dordrecht: Republic of Letters, 2014), 36-39.

37 Akami, Internationalizing, 180

${ }^{8}$ Cited in Ibid., 192.

39 "Liste Provisoire des Participants" [7 $7^{\text {th }}$ ISC conference, 1934], R4008/5B/9184/2381/Jacket1, LNA.

40 "Summary of the proceedings of the $7^{\text {th }}$ meeting of the executive committee of the ISC, Paris, 14 Dec 1934 ([published in] Jan 1935),” R4008/5B/14891/2381/Jacket1, LNA.

41 " 8 th meeting of the executive committee of the ISC: Preliminary draft agenda, 11 January 1936," R4005/5B/2381/2381/ Jacket2, LNA.

42 "Resume Des Deliberations" [8 $8^{\text {th }}$ meeting of the executive committee of the ISC], 18 Jan 1936, R4011/5B/21696/2381/Jacket2, LNA.

43 Kittredge to Walker, 21 Jan 1936, RG 1.1/Ser 100S/Box 105/F 954, RF, RAC.

44 Walker to Kittredge, 17 Jan 1936, RG 1.1/Ser 100S/Box 105/F 954, RF, RAC.

45 "Agenda of the $9^{\text {th }}$ ISC, Madrid, 27-30 May 1936," R4011/5B/21696/2381/Jacket3, LNA.

46 The IIIC, "Members of the ISC" [1937], included in Scroggs to Walker, 9 Dec 1937, RG

1.1/Ser 100S/Box 105/F 956, RF, RAC.

47 Akami, Internationalizing, 190-191.

48 Ibid., 215.

49 Ibid., 219.

5o Ibid., 79-80, 147.

${ }^{11}$ Ibid., 77.

52 Ibid., 229-243.

53 Uramatsu included in [the List of the participants of the $8^{\text {th }}$ ISC conference], attached to a letter from Chalmers Wright to Sir, 1 Aug 1935, but not in the formal list, attached to a letter from Cleeve to Chalmers Wright, 12 Aug 1935, NOOCR-362/K.I.1 t, UNESCOA.

54 Akami, Internationalizing, 164.

55 "Liste Provisoire Des Participants" [ $7^{\text {th }}$ ISC conference, 1934], R4008/5B/9184/2381/Jacket1, LNA.

${ }^{6}$ Akami, "Experts," 167.

57 Matsushita Denkichi, Chūken zaibatsu no shin kenkyū: Kantōhen, Tokyo: Chūgai sangyō chōsakai, 1937, 213; ILO, International Labour Conference, Eighteenth Session, Record of Proceedings, Geneva, ILO, 1934, XIX. I thank Onozaka Hajime for this reference.

${ }^{8}$ ILO, International, XIX.

59 Matsushita, Chuken, 226.

6o Takahashi Rikiya, "Senkanki Nihon no kokusaihō jitsumu to Tachi Sakutarō," Ajia Taiheiyō tokyū, 28 (March 2017): 245-259.

${ }^{61}$ Shinohara Hatsue,"Nichibei no kokusaihōkan o meguru sōkoku," Kokusai seiji, 102 (Feb 1992), 123-124.

62 The issue of 'reform of international law' and 'Peaceful Change' will be one significant point to examine. See, for example, Tachi Sakutarō, "Saikin kokusaihōgaku umi ni tōzeraretaru isseki no hamon," KHGZ, 34 (5) (1935): 1-29.

63 Takahashi Rikiya, "Tachi Sakutarō igo," KHGZ, 116 (3) (2017), 129-130, 132.

64 "Kaihō," KHGZ, 33 (5) (May 1934), 505; "Kaihō," KHGZ, 34 (1) (Jan 1935), 96.

65 "Kaihō," KHGZ, 35 (9) (Nov 1936), 101.

66 "Third provisional list of delegates and participants [of the $9^{\text {th }}$ ISC conference]," May 1936, R4011/5B/21696/2381/Jacket3, LNA.

67 After 1945, he became minister of education, Diet member, president of the Supreme Court, and judge of the International Court of Justice.

$68 \mathrm{https}$ ://www.ciup.fr/maison-du-japon/en/history/ accessed on 12 May 2020.

69 A list attached in the letter from Scroggs to Walker, 15 Nov 1937, RG 1.1/Ser 100S/Box 105/F 956, RF, RAC. 
70 "Kaihō," KHGZ, 36 (10) (Dec 1937), 73-74.

${ }^{71}$ The ISC's Euro-centricity was clear in its "colonial studies," which was prepared as one of the major topics for the conference theme, "peaceful change." Its scope was entirely European, and Yamada, who had certain knowledge on the issue, did not refer to the study at the conference.

72 Akami, Soft Power, 169-170.

73 https://www.mitsuipr.com/sights/historic-places/o5/, accessed on 20 May 2020.

74 In 1948, when Japan was still under the Allied occupation, he attended the MRA conference at Los Angeles with his wife and a few MRA members from Japan, and he became the chair of the MRA House in Odawara in 1952.

75 Mitsui to Monsieur le Directeur [Bonnet], 22 June 1938, RG 1.1/Ser 100S/Box 111/F 1015, RF, RAC.

${ }^{76}$ Kittredge to Walker, 30 June 1938, RG 1.1/Ser 100S/Box 111/F 1015, RF, RAC. Mitsui's letter suggested two other participants were Kiyosawa [Kiyoshi] and Satō [Junzō], but the fourth person is unclear. Mitsui to Monsieur le Directeur [Bonnet].

77 Kittredge to Walker, 30 June 1938, RG 1.1/Ser 100S/Box 111/F 1015, RF, RAC.

${ }_{78}$ Mitsui to Monsieur le Directeur [Bonnet], 22 June 1938.

79 Rōyama's name was listed as 'Seido'. The other three were: Kojima Seiichi (Hōsei) on "Brief overview of the main lines of Japan's foreign economic policy in recent years"; Kada Tetsuji (no institution) on "The main social and economic factors that have influenced the recent economic policy revolution"; and Sugimori Kojiro (Waseda) on "Main political factors.” Mitsui to Monsieur le Directeur [Bonnet], 22 June 1938.

80 After the war, Yanaihara went back to the university, transformed colonial policy studies to political economy and contributed to the foundation of the Japanese Association of International Relations in 1956, while he also was chancellor of the university in 1951-57.

${ }^{81}$ Kittredge to Walker, 30 June 1938, RG 1.1/Ser 100S/Box 111/F 1015, RF, RAC.

82 Ibid.

83 Her handwriting note in Ibid.

84 Walker to Kittredge, 18 Jul 1938, RG 1.1/Ser 100S/Box 111/F 1015, RF, RAC.

85 Gross to Kittredge, 25 Jul 1938, NOOCR-364/K.I.4b, UNESCOA.

86 Kittredge to Gross, 2 Aug 1938, NOOCR-364/K.I.4b, UNESCOA.

87 Mitsui to Sato, 12 May 1939, NOOCR-362/K.I.1.v., UNESCOA.

881939 participation file, NOOCR-362/K.I.1.v., UNESCOA.

89 He became managing director of the BIS in 1943, and posted to North China. Here he examined economic situations and communicated intelligence to the Japanese government. After the war, he worked with the Occupation force and for Japan's economic recovery.

9o Yokohama shōkin ginkō, Yokohama shōkin ginkō zenshi, vol. 6 (Tokyo: Tokyo ginkō, 1984), at https://shashi.shibusawa.or.jp.

${ }^{91}$ On Mitsui Trading Company's activities in North America, see Kamiyama Kazuo, Hokubei ni okeru sōgōshōsha no katsudō, 1896-1941 nen no Mitsui bussan, (Tokyo: Nihon keizai hyoronsha, 2005).

92 Rietzler, “American,” 232-233.

93 Ibid., 234-35, 240

94 The center started in 1930 almost as an information center on the League for the Americans and American organizations in Geneva, with Rockefeller Foundation and CEIP money. Ibid., 225-229.

95 They included James Shotwell, Alfred Zimmern, Jacques Lambert, Ludwig von Mises, and Herbert Tingsten.

96 Kittredge to Walker, 16 June 1936, RG 3/Ser 910/Box 7/F 60, RF, RAC.

97 Ibid. 
98 E.H. Carr, The Twenty Years' Crisis, 1919-1939 (London: Papermac, 1993, first published in 1939), 93.

99 Kittredge to Walker, 16 June 1936.

100 Ibid. 